\title{
SOME ASPECTS OF LIFE AND POLITICS IN THE UNITED STATES OF AMERICA IN I932)
}

To the present generation of young Americans the so-called two party system appears to be an almost unshakeable and permanent feature of the nation's polity. Several well-known American liberals (as, for instance, Senator Paul Douglas of Illinois and Walter Reuther, head of the powerful United Automobile Workers), who, in earlier years had reposed little faith in the Republican and Democratic parties, have gradually veered round to the view that the quest for reform must be pursued within the framework of the two major political parties. "Third parties" on the American scene have become virtually skeletonized for various reasons and their plans and platforms receive scant notice at the hands of the media of mass communication. With the advent of good times during the war and post-war years, organizations advocating a radical reconstruction of the social and cconomic order have found a progressively shrinking audience. Radicalism among the intelligentsia has become a factor of minor significance. Will there be any important changes in such a state of affairs if the current business "recession" continues much longer or intensifies? Do "bad times" favor the growth of militant parties of protest and dissent? Few students of the American scene expect that in the foreseeable future there will be any widespread move away from the two traditional parties. It is interesting in this connection to examine the developments in the United States a quarter of a century ago when the nation was plunged into one of the most serious economic crises in its annals. This paper will examine some aspects of life and politics in the United

1 The writer is grateful to Mr. Norman Thomas for giving him several interviews and patiently answering many letters. Mr. Thomas generously gave his permission for the use of material in his personal papers. The writer is also thankful to the authorities of the New York Public Library, the Duke University Library, the Houghton Library of Harvard University, and the Milwaukee County Historical Society for permitting him to consult manuscript collections in their custody. 
States in 1932 with special reference to the campaign of the Socialist Party of America to emerge as a significant political force.

Nineteen thirty two was a bleak year for millions of Americans. A depression of unprecedented magnitude held the land in its vicious grip. Hunger and destitution - common enough in many other parts of the world - raised their ugly heads in many an American community. Over eleven and a half million Americans were without jobs. ${ }^{1}$ Thousands of others who were fortunate enough to hold gainful employment were afraid and disheartened. They were afraid of losing their jobs; they were troubled because their incomes were gravely lowered by cuts in wages and reduction in hours of work.

Industrial wage earners, farm workers and farmers were the hardest hit by the depression. Unskilled industrial laborers were the first to be laid off by factories, and they had very few opportunities to find new positions. But even skilled workers were laid off by the score in some fields like the construction and durable goods industries that were most affected by the depression. As a result, a high incidence of unemployment prevailed among engineers and allied technicians. ${ }^{2}$

Farmers were seriously hurt by the depression. Prices of farm products tumbled down to levels that had not been encountered over several decades. ${ }^{3}$ Thousands of farmers went bankrupt and faced the threat of being evicted from their farms by foreclosure on mortgages. Over half a million farm laborers were without employment while declining farm prices resulted in a drastic reduction of wages for those who managed to retain their jobs.

Numerous middle class families were injured by the business collapse. Nine million savings accounts were wiped out during the three years of the depression and, in the same period, 85,000 businesses failed, involving liabilities of $\$ 4 \frac{1}{2}$ billions..$^{5}$ Some wealthy Americans were ruined by the business collapse and many who had engaged in imprudent speculation sustained severe financial losses. The "paper"

1 Estimate for October 1932 by the American Federation of Labor. Estimates made by a number of organizations showed variations because of differing definitions of "unemployment" and of deficiencies in the statistical material available. Two scholars who examined the various estimates came to the conclusion that the method adopted by the American Federation of Labor was "careful and thorough and results in an unemployment figure that is probably nearest to being the correct under the definitions adopted". Russell A. Nixon and Paul A. Samuelson, Estimates of Unemployment in the United States, in: Review of Economic Statistics (Cambridge, Mass.), XXII (August, I940), IOI-I I.

2 Broadus Mitchell, Depression Decade (New York, 1947), 97.

3 Daniel Ahearn, Jr., The Wages of Farm and Factory Laborers 1914-1944 (New York, I945), 146 .

4 Ibid., I 72

B Dixon Wecter, The Age of the Great Depression (New York, 1948), I6. 
wealth of owners of non-landed capital declined very much owing to the fall in the prices of securities. The net profits of corporations also declined considerably. But, as many corporations had followed a policy of building up reserves for the protection of stockholders, "the cash income of the owners of American corporations... was maintained to a truly remarkable degree." 1

The feeling was widespread among all sections of the American people that the country was passing through one of the gravest crises in its history. There was considerable discussion on whether traditional political processes would avail in curing the nation's malaise. That ominous word "dictatorship" began to make its appearance in the columns of American journals and the implications of such a trend were discussed both seriously as well as facetiously. "Does America Need a Dictator?" asked the editor of the American Political Science Review, in a disquisition. ${ }^{2}$ The Nation ran a series of articles by various dignitaries under the caption "If I were a Dictator." 3 The American Legion placed itself on record as having no confidence in the efficacy of "existing political methods"."

There were, however, few voices raised actually demanding the establishment of a dictatorship in the country. Some observers looked enviously at Italy where a "strong man" had maintained order and even made trains run on time. A popular historian expressed the view that the advent of an American Mussolini would not be in contradiction to American national character. "The United States with its sentimental devotion to leaders, its 'Teddies' and its 'Cals', its love of efficiency and getting things done, looked towards Rome", wrote James Truslow Adams. ${ }^{5}$ One New York publisher asserted that the

1 Paul Douglas, Dividends Soar, Wages Drop, in: World Tomorrow (New York, N.Y.), $\mathrm{XV}$ (December 28, I932), 61 I-I2. "While dividend and interest payments did begin to fall off in 1932, wages declined still more. While wages in manufacturing for the nine months from January to September 1932 , averaged less than 43 per cent of their totals in 1926 and 1929 , the dividend and interest payments were at a rate only five per cent below those of 1929 and 64 per cent above those of 1926 . It should moreover be remembered that the fall in living costs made the gain in the real income of the stock and bondholders even greatcr than is indicated by the monctary figures alone."

2 Frederick A. Ogg, Docs America Necd a Dictator? in: Current History (New York, N.Y.), XXXVI (September, I932), 64I-48. The author answered the question in the negative.

3 Among the writers were Morris L. Ernst, Oswald Garrison Villard, Stuart Chase, Glenn Frank, Lewis Mumford and William Allen White. Nation (New York, N. Y.), CXXXIII (1931); CXXXIV (1932).

4 Walter Lippmann, Interpretations $1931-1932$ (New York, 1932), 30.

5 James Truslow Adams, Shadow of Man on Horseback, in: Atlantic Monthly (Concord, N.H.), CXLIX (January, 1932), Io. Adams added that he could not foretell what would happen in the United States "except that life gocs on and on, and institutions forever change". 
time had come for the President of the United States to assume dictatorial powers and to rule the nation under martial law. ${ }^{1}$ There were others, influential in industrial and commercial circles, who believed that the President should assume emergency powers. Owen D. Young, chairman of General Electric, made a suggestion to this effect in a widely-publicized commencement address at Notre Dame University. ${ }^{2}$ The chairman of the United States Chamber of Commerce, Julius $\mathrm{H}$. Barnes, urged the creation of a high-powered advisory National Economic Council to serve as a "general board of strategy" working towards the goal of orderly economic progress. ${ }^{3}$

Large numbers of Americans who were dismayed by the failure of political and business leaders, dreamed about the emergence of a new and resolute leadership that would lift the nation out of despondency and economic chaos. The American people, wrote Walter Lippmann, "are looking for new leaders, for men who are truthful and resolute and eloquent in the conviction that the American destiny is to be free and magnanimous, rather than complacent and acquisitive." 4

In Park Avenue penthouses as well as in Greenwich Village gatherings, heated were the discussions on the possibility of revolutionary outbreaks in the United States. "The word revolution is heard at every hand", reported George Soule in an article in Harper's Magazine. Elmer Davis was worried because "solid and sensible citizens" as distinct from the "speakeasy intelligentsia" were asking him whether a revolution was imminent. ${ }^{6}$ Testifying before a Congressional committee, a spokesman for the American Federation of Labor declared that there was a possibility of a revolt among workers unless something tangible was done to relieve their distress. ${ }^{7}$ Lloyd's of London announced that for the first time in their history they were selling riot and civil commotion insurance in quantity to American clients. ${ }^{8}$ National Guard authorities in Illinois drew up detailed instructions for the guidance of their men on the techniques of dispersing unruly

1 Bernarr Macfadden, in an editorial in Liberty; quoted by Ogg, op. cit., 646.

${ }^{2}$ New York Times, June 6, 1932, p. 4.

3 Julius H. Barnes, Government and Business, in: Harvard Business Review (Cambridge, Mass.), X (July, 1932), 41 I-19.

4 Lippmann, op. cit., 29.

5 George Soule, Are We Going to have a Revolution?, in: Harper's Magazine (New York, N. Y.), CLXV (August, 1932), 277.

- Elmer Davis, The Collapse of Politics, in: Harper's Magazine, CLXV (September, I932), 387 .

7 Testimony of Edward F. McGrady before the Senate Manufactures Committee. American Federation of Labor Weekly News Service (Washington, D. C.), XXII (May 14, 1932), I.

B Wecter, op. cit., I6. 
mobs. The Guardsmen were directed, if necessary, to shoot "with full charge ammunition ..."1

The American proletariat, however, showed a truly remarkable unwillingness to stage any kind of revolution. ${ }^{2}$ Leaders of the biggest organization of the working class - the American Federation of Labor - refused to be tainted with radicalism and vigorously denied the existence of any class struggle in the United States. ${ }^{3}$ As the proletarians continued to queue up at the bread lines instead of setting up barricades, many were the gibes that were thrown at them. How could the American who, when he lost his temper, fiddled with his radio to listen to the puerile rantings of "Amos 'n Andy", ever be expected to start a revolution, asked writer George Sokolsky.

"As long as every American believes that he has as many chances as John D. Rockefeller to become a millionaire, to join a country club, and to get into the upper social brackets, he will not become a revolutionist. Hungry, he will pull in his belt. Annoyed, he will vote for a Democrat. Angry, he will demand beer. Despairing, he will telephone his Congressman..." 4

The American masses were hardly capable of intelligent thinking, asserted another indignant scribe, Frank R. Kent. "Personally, I don't think there is anytbing much going on in the minds of the American people because I think relatively few of them have minds", Kent added. 5

The depression and the human suffering that it brought with it, did make a powerful impact on a significant segment of the intellectuals - the socially-conscious writers, teachers, and clergymen. Many of them had harbored misgivings about the ethics of America's "business

1 The headquarters of the $33 \mathrm{rd}$ Division of the Illinois National Guard secretly circulated a booklet entitled "Emergency Plans for Domestic Disturbances". Excerpts from it were quoted by World Tomorrow, XV (April, 1932), I03.

2 The nearest approaches to mass action during the year were the encampment in Washington D. C., of the so-called Bonus Army and the "siege" of Council Bluffs and Sioux City in Iowa by angry farmers led by the National Farmers' Holiday Association. Despite a few alarmistic reports, neither of them constituted a threat to the safety and security of the established order in the United States.

3 William Green, president of the Federation, declared that labor "has steadfastly refused to isolate itself from other groups of American citizens, to develop and emphasize class lines..." American Federation of Labor Weekly News Service, XXII (May 7, 1932), I. 4 George Sokolsky, Will Revolution Come?, in: Atlantic Monthly, CL (August, r 932), I9r. "Amos 'n Andy", a radio comedy program, is still on the air and has an extensive and loyal following.

${ }^{5}$ Frank R. Kent in a symposium on The Future of American Government, in: Forum (Concord, N. H.), LXXXVII (May, 1932), 212 , 
civilization", but few believed in or desired radical innovations in the political and economic organization of the country. They anxiously looked around for a "liberal" leader among the ranks of politicians of the two major political parties under whose banner they could continue the struggle for reform and progress. There were, however, others to whom the tactics of "liberalism" appeared to be futile and ineffective. Liberalism, said Lincoln Steffens, had merely brought about the reform of the graft system and an improvement in the administration of rackets "which have increased in number, power, value and efficiency."' These men regarded the activities of the two major parties - Republican and Democratic - as cheap stunts to ensnare the voters. Criticisms of the established social and economic order emanated also from gatherings of churchmen. A resolution adopted by the quadrennial conference of the Methodist Episcopal Church asserted that the "present industrial order is unchristian, unethical and anti-social because it is largely based on the profit motive which is a direct appeal to selfishness." The General Assembly of the Presbyterian Church exhorted churchmen to be active in the continuing fight against social abuses. A Roman Catholic Bishop, Urban J. Vehr, condemned the "system" that had permitted millions to go hungry and a few to control the wealth of the nation. ${ }^{3}$ The Central Conference of American Rabbis declared that the capitalist order was "neither economically sound nor can it be morally sanctioned." 4 The rabbis advocated "immediate legislative action in the direction of changes whereby social control will place the instruments of production and distribution as well as the system of profits, increasingly within the power of society as a whole."5

Perhaps never before in the annals of America had there been such a flight of intellectuals away from the Republican and Democratic parties as took place in 1932. 1932 was an election year and many intellectuals were repelled by what they regarded as the "political degradation" displayed by the two major parties. The deliberations at their conventions appeared to have little relation to the harsh realities of the depression. On the other hand, the issue of Prohibition figured in an important manner in the calculations of the politicians. Walter Lippmann noted "the total absence of any evidence of economic insurgency" at the Republican convention and felt that "nothing

1 Lincoln Steffens, Bankrupt Liberalism, in: New Republic (New York, N.Y.), LXX

(February 17, 1932), Is.

2 The Methodists Fall Back and Advance, in: World Tomorrow, XV (July, I932), I99.

3 Speech before a meeting of the Catholic Conference on Industrial Relations. American

Federation of Labor Weekly News Service, XXII (May, 1932), 1.

4 We Salute the Rabbis, in: World Tomorrow, XV (November 23, 1932), 486.

5 Ibid. 
important is to be decided here except the manner in which the party will take note of the popular revulsion against the Eighteenth [Prohibition] Amendment." 1 In the Democratic convention the veteran editor, Oswald Garrison Villard, found that "the question of beer and booze outranked everything else." " Disgusted with the attitude displayed by the leaders of the two major parties, a significant number of American intellectuals lent their support to the Socialist and the Communist parties. Despite widespread distress and dissatisfaction hardly anybody expected a "third party" to secure a mandate from the electorate for a revolutionary reconstruction of American society. There were many, however, who believed that owing to the extraordinary strains to which the nation had been subjected, a considerable volume of "protest" votes might go to third parties, especially to the Socialist party.

Several American writers have waxed eloquent about the political contest between Herbert Hoover and Franklin D. Roosevelt in 1932. In some instances their judgment appears to have been colored by their appraisal of Roosevelt's career as President. Some of his admirers tend to see in his campaign of 1932 a significant exposition of the principles of the "New Deal". Others who harbor an intense dislike for Roosevelt tend to see in the campaign the germs of an audacious philosophy that presaged a serious threat to the "American way of life". A careful study of the campaign leads to the conclusion that Hoover and Roosevelt did not differ basically in their approach to the problem posed by the depression. Both outlined cautious and conservative proposals which differed little in ideology or fundamentals but only in emphasis. They envisaged governmental action to provide unemployment relief only as a last resort. Both hailed charity as an American way of dealing with want. ${ }^{3}$ They proclaimed, however, that if conditions warranted it, they would not hesitate to use every resource of the Federal government for the relief of distress. Neither of them was apparently ready to acknowledge that such a point had been reached in the autumn of 1932 . Hoover's mind was tranquil on

1 Lippmann, op. cit., 286-87.

2 Oswald Garrison Villard, The Democratic Trough at Chicago, in: Nation, CXXXV (July 13, 1932), 26. Earlier, in an outspoken personal letter, editor Villard had condemned Franklin D. Roosevelt's "policy of talking mere glittering generalities". "You are", he wrote to Roosevelt, "playing the old politician's game of compromising and trimming and evading issues and we had the right to expect a great deal more from you". Villard to Roosevelt, June 17, 1932, Oswald Garrison Villard Papers, Houghton Library, Harvard University, Cambridge, Mass.

3 Herbert Hoover, The Memoirs of Herbert Hoover, 4 vols. (New York, I95 2), III, 56. For a statement of Roosevelt's views see The Public Papers and Addresses of Franklin D. Roosevelt, 13 vols. (New York, I938-r 950 ), I, 85 I. 
that score. His Surgeon-General had assured him that the general health of the American people was at a higher level than ever before in the history of the United States. ${ }^{1}$ Roosevelt asserted that his own measures of unemployment relief were a "model" to other states. Even as he spoke, in New York City alone, over half a million persons were dependent on charity for maintaining body and soul together. ${ }^{2}$

Neither Hoover nor Roosevelt placed before the electorate any comprehensive program for putting the unemployed back to work. The President claimed credit for having spent two billion dollars on public works - an amount, according to him, "greater than the whole expenditure during the previous thirty years, including the Panama Canal." ${ }^{3}$ Roosevelt blithely offered a variety of policies many of which were mutually contradictory. He talked of putting several thousands of the unemployed to work in afforestation, flood prevention, and waterway projects. In the same breath he cautioned that public works should be considered from the point of view of the ability of the Treasury to pay for them. ${ }^{4}$ He did not see much scope for obtaining funds for financing public works out of current revenues, and, if bonds were to be issued for the purpose, he promised to take care that they would be for "self-sustaining projects" only.

Roosevelt did not explain how even such an orthodox and moderate program of unemployment relief could be reconciled with his oftrepeated "pledge and promise" to prune down the Federal expenditure and to balance the budget. A balanced budget, Roosevelt announced, was "the one sound foundation of permanent recovery." 5 He taunted Hoover with having failed to achieve so desirable an objective and added that the President's "extravagance and improvidence" had placed the country on the road to bankruptcy. Reduction of governmental expenditure, thundered the Democratic standard bearer, was "one of the important issues of the campaign." No one could enter his cabinet unless he gave an unqualified pledge to carry out the economy plank of the Democratic platform, he asserted.6

Roosevelt warned that he would not hesitate to increase taxes if such an action was needed to keep the people from starvation. He did not elaborate on the fiscal policies that he had in mind, but dangled before

1 Hoover, op. cit., III, 3 It.

2 This figure was given in a nationwide radio speech over the Columbia Broadcasting System by Harvey D. Gibson, chairman of the Emergency Unemployment Relief Committec, New York Times, Octobet II, I932, p. I9.

3 Hoover, op. cit., III, 3 I I.

4 The Public Papers... of Franklin D. Roosevelt, op. cit., I, 794.

5 Ibid., 806.

- Ibid., 809. For some revealing comments on this speech see Samucl I. Rosenman, Working with Roosevelt (New York, 1952), 86. 
the public the tempting prospect of "several hundred millions of dollars a year" flowing out of a Federal tax on beer. The Governor also made occasional references to the need to "restore the purchasing power of the people" but did not volunteer any information on how he would fit in that objective with the rest of his proposals. ${ }^{1}$

All through the campaign the Democratic candidate tried to make it appear as though the depression was almost single-handedly brought about by the efforts of Mr. Hoover. The President, for his part, grimly warned the American people that the election of his opponent might bring on the horrors of a collectivist economy. The Democrats retaliated in kind when John W. Davis, unsuccessful Democratic Presidential candidate in 1924, accused Hoover of having "followed the road to socialism at a rate never equalled in time of peace by any of his predecessors." 2 To Mr. Hoover, apostle of "rugged individualism", this charge was, perhaps, the unkindest out of all.

The parties that claimed to be "socialist" saw in the depression a fulfilment of the Marxist prophecy relating to capitalism in crisis. They were dismayed to find that popular support for the cause did not increase significantly despite the correctness of their "theory". However, they entered the electoral fray with optimistic expectations of a greatly increased vote.

The Socialist Labor party, oldest of the Marxist groups, named Verne L. Reynolds, a steam fitter turned advertisement executive, as its standard bearer. The nominee fervently exhorted the thirty three delegates to the national convention held in New York City to go forth into the four corners of the land and swell the ranks of the party with recruits from the working class. The party's platform envisaged collective ownership and control of industries to be attained by the incorporation of national industrial unions into "One Big Union". ${ }^{3}$ Party spokesmen as well as their official organ, the Weekly People, asserted that the S. L. P. program was the only true revolutionary path for the proletariat and vehemently denounced the "reformism" of other socialist parties.

1 The Public Papers... of Franklin D. Roosevelt, op. cit., I, 853.

2 John W. Davis, Why I am a Democrat, in: New York Times, Oct. 30 , I932, Sec. II, p. 2.

3 New York Times, May 2, I932, p. 4; Sidney Hertzberg, Political Dissent in 1932, in: Current History, XXXVII (November, 1932), 16 I-66. Aside from the parties that claimed to be socialist, many other parties entered the electoral contest on a national and regional scale. For a humorous account of the activities of these groups see James Oneal, Messiah vs. Messiah vs. Messiah, in: American Mercury (New York, N. Y.), XXVII (October, I932), r77-83. See also R. V. Peel and T. C. Donnelly, The 1932 Campaign (New York, 1935), $201-06$. 
The Communist party held its convention in Chicago and renominated William Z. Foster as its candidate with J. W. Ford, a prominent Negro party member, as his running mate. Foster announced to the cheering delegates that "before long a Communist will stand at the head of the American government, a Soviet government."1 The Communist leader outlined six "immediate demands" for which his party would struggle and he listed them as unemployment and social insurance, emergency relief to farmers, an end to wage cuts, equal rights and self-determination for Negroes, and opposition to "imperialist war" and "capitalist terror". Foster emphasized, however, that the only salvation for the American people lay in a revolutionary overthrow of capitalistic institutions.

In a campaign volume entitled: Toward Soviet America, Foster glowingly described the kind of life that Americans could enjoy after the attainment of communist salvation. The dictatorship of the proletariat would be established and a system of county, state, and national soviets would come into being. There would be prosperity for the farmer, abundance for the worker, liberation for women, and a new life of culture for children. Social and racial disabilities would be completely eliminated. All these and more would be accomplished by a wise and benevolent government that would be in the hands of a Central Executive Committee - the C. E. C. Among the functions of the C. E. C. would be the direction and control of the Supreme Court and other lower courts which would war unceasingly against the "class enemies of the toilers". The Democratic, Republican, and Socialist parties would be liquidated and special courts would be established to deal with counter-revolutionaries. "Parasites" like capitalists, clericals, and other non-producers would be disenfranchised. Among other excrescences to be speedily abolished would be such "political props of bourgeois rule" as the Y.M.C.A., Knights of Columbus, rotary clubs, the Odd Fellows, Masons, Elks, employers' associations and chambers of commerce. ${ }^{2}$

Undeterred by the implications of the Communist program as propounded by Foster, an impressive group of intellectuals publicly supported his candidacy. Included in the group were John Dos Passos, Theodore Dreiser, Waldo Frank, Edmund Wilson, Lincoln Steffens, Malcolm Cowley, Granville Hicks, Lewis Mumford, Matthew Josephson, Sherwood Anderson, and Clifton Fadiman. "Nobody in the world proposes anything basic and real except the Communists",

1 Quoted in Joseph North, The Communists Nominate, in: New Masses (New York, N.Y.), VIII (July, 1932), 4. A melodramatic account of the Communist party convention.

2 William Z. Foster, Toward Soviet America (New York, 1932), 268-343. 
declared Lincoln Steffens. ${ }^{1}$ His attitude was typical of the sentiments of those who gave their support to the Communist ticket. They were tremendously impressed by reports of the progress made by the Soviet Union and by its claim not only to have abolished unemployment but to have provided a more meaningful life to the common people than capitalism had offered. They cast their support to the Communist party in the belief that thereby they would be furthering the cause for which the Soviet Union stood.

The most important of the "third parties" in the United States in I932 was the Socialist party of America. At its convention held in Milwaukee, Wisconsin, the party named Norman Thomas as its presidential candidate. James Maurer of Pennsylvania, a veteran party leader, was chosen as the vice-presidential nominee. ${ }^{2}$ Thomas had served as the party's standard bearer in 1928 and had since become its best known spokesman. Many Socialists were of the opinion that his impeccable "American" background would dispel charges that the party was run by foreign-born radicals. ${ }^{3}$ His courage and integrity were acknowledged even by political opponents of the party. His educational and clerical qualifications gave him access to middle class groups that usually fought shy of Socialist speakers. By his energetic activities in behalf of workers and by his concern for public welfare Thomas injected a new spirit in the party. In conferring on him the honorary degree of Doctor of Literature in 1932 his alma mater, Princeton University, described Thomas as a "valiant and distinguished son of Princeton", who, at the bidding of his conscience "gave up a conventional form of ministry to his fellow men to become the fearless and upright advocate of change in the social order." The party that Thomas led in the campaign of 1932 was small and its finances were in sorry

1 Quoted by Granville Hicks, Where We Came Out (New York, 1954), 36.

2 For an autobiographical account of some of the highlights in the career of Norman Thomas, see A Socialist's Faith (New York, 195 I); see also James H. Maurer, It Can Be Done (New York, 1938).

3 In 1931, 32 per cent of the total membership of the Socialist party belonged to the socalled "language federations". "Language federations" existed for Americans of Bohemian, Finnish, Italian, Jewish, Jugoslav, Lithuanian and Polish antecedents. In 1932 the party's membership increased and "language federations" accounted for I 8 per cent of the total. Source: Report to the Special National Convention, Chicago, March 26-29, I937, Archives of the Socialist party of America, Manuscripts Division, Duke University Library, Durham, North Carolina. "The future of the Socialist party in America", said a leader of the Finnish Federation, "is in the native born stock. The days of the language federation are past. They will continue to live and function, but they should not be expected to become an active, virile element again." W. N. Reivo, The Finnish Socialists in America, in: The March of Socialism: Journal of the Serenteenth National Convention of the Socialist Party (Milwaukee, 1932), 13. 
shape. ${ }^{1}$ Personal and factional differences in the party stood in the way of effective and unified action. Despite these limitations the Socialist presidential campaign of 1932 led by Norman Thomas was one of the most vigorous in the annals of American third parties.

Thomas declared that there were no vital differences between the Democratic and Republican parties. They were merely "two bottles with different labels and both empty of any medicine for the sickness of our times."' $\mathrm{He}$ challenged the attempts of Democratic orators to present Roosevelt as an enemy of Wall Street and asserted that the Democratic nominee "did not lift his little finger" to control Wall Street while he was Governor of New York. ${ }^{3}$ Roosevelt, he said, was closely allied with unsavory Democratic city bosses like Frank Hague of New Jersey while Hoover was willing to fraternize with such Republican bosses as Bill Vare of Philadelphia.4

The Socialist leader assailed the platforms of the two major parties and the campaign issues as posed by their respective nominees. Hoover's program was "opportunistic, confused, only sure of one thing, and that, its devotion to private profit." 5 Despite his constant preaching of the virtues of rugged individualism, said Thomas, Hoover had sponsored extensive governmental intervention in the economy by his measures relating to tariffs, the Farm Bureau, and the Reconstruction Finance Corporation. But the purpose for which Hoover sponsored such intervention, Thomas charged, was "always

1 The total membership of the party in $x 932$ was 16,863 . Receipts from membership dues amounted to the meager sum of $\$ 6,724.99$. Source: Report to the Special Convention, Chicago, March 26-29, x937, Archives of the Socialist Party.

2 Radio speech from Madison, Wisconsin, September 25, 1932, Norman Thomas Papers, Manuscripts Division, New York Public Library, New York.

${ }^{3}$ In a speech at Providence, Rhode Island, Thomas posed these questions to Roosevelt: "Will you state specifically when you or your party officials called on the administration to check the Wall Street boom and what specifically you advised the administration? What did you do as Governor of New York after January 21, 1929, to bring Wall Street to terms?" New York Times, August 22, 1932, p. 2. Walter Lippmann characterized as "preposterous" the widespread feeling in the South and the West that Wall Street feared Roosevelt and added that "if any Western Progressive thinks that the Governor has challenged directly or indirectly the wealth concentrated in New York City, he is mightily mistaken." Lippmann, op. cit., 261.

4 Boss Hague arranged a giant rally for Roosevelt in Jersey City, New Jersey, and shared the platform with the candidate. Hague sternly rebuked Republicans during the campaign for presuming to accuse the Democratic leadership of radicalism. "The Republicans can't hang radicalism on us and make it stick", he said. "All our leaders are conservative....the national committee of which I have been a member for fifteen years is conservative. And ours is a party of the interests and industries.... To be against business would be to be against the working man." World Tomorrow, XV (October I2, 1932), 34I.

5 Speech over the Columbia Broadcasting System, July 13, I932, Thomas Papers. 
for the sake of the businessman in the hope that if the businessman prospers something may splash over to the farmer and to the worker."1 The difference between Hoover and the Socialists was not on the desirability or otherwise of collectivism and governmental intervention in the economic sphere. "It is a question of the kind of collectivism, and for whose benefit government shall act - the profit takers or the workers; speculators or consumers", he said. ${ }^{2}$ Thomas characterized the Democratic party as an incongruous assemblage of incompatible elements. Governor Roosevelt, according to him, had no political philosophy or program except a great desire to hold office, and was wandering about like an "amiable political Santa Claus" promising to be all things to all men. ${ }^{3}$

In numerous speeches and articles the Socialist leader expounded his own views on the immediate measures that should be undertaken to lead the country out of the depression. Thomas felt that the full resources of the nation should be mobilized to fight unemployment. It was folly to remain passive in the face of the eroding sickness of mass unemployment, he said. On many a platform he declared that unemployment relief was of far greater importance than balancing the budget. ${ }^{4}$ Only the Federal government with its extensive fiscal powers could adequately undertake the task. If all else proved inadequate, the Federal government should implement a program of direct money subsidies to unemployed consumers which, in turn, would have a very healthy impact on the economy.
"We would... subsidize consumers or consumption instead of subsidizing producers or production as we have done so long by tariffs. I think we should soon discover that the surest way to start up industry was by giving fathers and mothers enough to begin to purchase the things they sorely needed for their children."5

Thomas also called for a ten billion dollar program of public works and assailed those who advocated a reduction of socially important expenditure in the name of economy.

1 Spech over the National Broadcasting Company's network from Madison, Wisconsin, September 25, 1932, ibid.

2 Speech over Radio Station WEVD, New York City, August 12, 1932, ibid.

${ }^{3}$ Radio speech, September 3, I932, ibid.

4 Speech over the Columbia Broadcasting System, June 10, 1932, ibid.

5 Speech over Radio Station WOR, New York City, September 18, 1932, ibid. 
In his rejection of the balanced budget as an ideal to be attained at all costs, his opposition to false economy, his advocacy of a massive program of public works, and his call for direct monetary relief to consumers as a means of stimulating business recovery, Thomas displayed a grasp of fiscal devices that was superior to that of other candidates. ${ }^{1}$ In regard to another measure that he advocated Thomas was on more debatable ground. Thomas believed that the nation would be in better economic health if the national debt and the burden of interest payments could be eliminated. ${ }^{2}$ Towards the end of the campaign Thomas put forth a suggestion for a capital levy to wipe out the national debt. He argued that since the debt had been contracted as a result of the world war into which the "owning class" had put the country, the fairest way of liquidating it would be through the capital levy. The impost could be levied once and the revenue that it would yield could take care of the debt and also serve to hasten "the transfer of natural resources, public utilities and great monopolies to social ownership", the Socialist leader said. ${ }^{3}$

In a number of speeches Thomas expounded the demands for labor legislation contained in the Socialist platform. He called for a 3o-hour week without a reduction of wages; a comprehensive system of free public employment agencies; a compulsory system of unemployment

1 Many important socialist leaders of Europe and Great Britain clung to orthodoxy in tcspect of fiscal and financial measures for combating the depression. A noteworthy exception was provided by the leadership of the Social Democratic party of Sweden. On this point, see Adolf Sturmthal, The 'Tragedy of European Labor I918-1939 (New York, 1943), 98-175. For an account of the financial orthodoxy of the second Labour Government in Great Britian, see G. D. H. Cole, A Short History of the British Working Class Movement (London, 1948), 430-37; and C. R. Attlee, As It Happened (London, 1954), 72-74.

2 Speech over Radio Station WEVD, New York City, August 12, 1932; Speech over Radio Station WOR, New York City, September 18, 1932; Thomas Papers. Thomas was, perhaps, influenced to some extent by alarmistic works about the evil of national debts, particularly by Lawrence Dennis's Is Capitalism Doomed? (New York, 1932), and Kuno Renatus's The Twelfth Hour of Capitalism(New York, 1932). In a review of the two works Thomas sharply criticized the conclusions of the authors. See World Tomorrow, XV (June, I932), I 86.

${ }^{3}$ For the full text of the speech see New York Timcs, October 21, 1932, p. 14. In a critical editorial the newspaper expressed regret that a fine gentleman like Thomas could advocate a course "so incautious, ill-founded, misleading and inflammatory." Open Scsame on Promises, in: New York Times, Octobcr 22, 1932, p. 14. Thomas informed the writer of this article that he did not, as some critics charged, purposely wait till the cnd of the campaign for putting forth his demand for a capital levy. He had asked a fcllow Socialist, Prof. Maynard Kruegcr of Chicago University, to send him material on a capital levy "of which I was at the time ready to be a strong advocate." "I never did get all that I wanted but I did get some material and so I spoke at Columbus .... I should have said more on the subject and carlier, if I had gotten the material which I thought I ought to have had." Thomas added that in his advocacy of the capital levy he was influenced by the writings of the British Socialist, Hugh Dalton. Thomas to writer, January 17, I955. 
compensation with adequate benefits based on contributions by the government and employers; old age pensions for persons sixty years of age and over; health and maternity insurance; improved systems of workmen's compensation and accident insurance; the abolition of child labor; and adequate minimum wage laws. Sharply critical of the record of the United States Supreme Court in the sphere of social progress, Thomas advocated the passage of a "Workers' Right Amendment" to the Constitution which would empower Congress to undertake these and other measures for the welfare of the people. ${ }^{1}$ Pointing out that the two major parties had not offered any comprehensive program for labor, Thomas argued that even on its old principle of rewarding friends and punishing enemies organized labor should support the Socialist ticket.

The Socialist candidate was much less clear in his approach to the problems of the farmers. In one of his few references to the crisis in agriculture, Thomas declared that his program "includes the creation of a Federal Marketing Agency for the purchase and marketing of agricultural products, the socialization of federal land banks and the extension by these banks of long term credit to farmers at low rates of interest." 2

Thomas asserted frequently that the malady that had prostrated the United States could not be cured within a capitalistic framework. He rejected proposals for planning under capitalism proposed by such men as Gerard Swope, George Soule, and Walter Lippmann. What was needed, according to him, was not merely a plan but a purpose. He would accept nothing less than the purpose of a "co-operative commonwealth" that only socialism could usher in. Without socialization of "those natural resources which no man made and those aggregations now owned by absentee owners" no economic plan could be expected to benefit the community of workers.

"It is this transfer of natural resources, the great means of production, the banking system, the public utilities from private to public hands, which is the vital issue of our time.... There is a defeatist sentiment among us which says that we cannot col-

1 Thomas was critical of the Supreme Court's record in the sphere of social legislation and held that it had done "more damage to social progress in America than any Congress." Speech at Morristown, New Jersey, New York Times, October 29, 1932, p. 10. He said that the power of the Court "to enact its social prejudices into law under the guise of interpreting the Constitution" should be curbed.

2 Speech over the Columbia Broadcasting System, July 13, 1932, Thomas Papers. Thomas told the writer that he had spoken to many farm groups, "but never got big audiences or very much help from farm leaders." Thomas to the writer, January 17, 1955. 
lectively manage our own business. We can, if we have the right ideals, if we rid our souls of the curse of racketeering bred by the low standards of the acquisitive society." 1

Workers of hand and brain, Thomas declared, should cast aside their lethargy and organize for political action. The Socialist party would be the most efficacious instrument for such action because it alone stood for social ownership and planned production. Declared Thomas in a great rally in New York's Madison Square Garden:

"Why vote Socialist? For the sake of yourselves and your children, for the sake of the whole company of workers with hand and brain, of every race, creed and clime, and the future of mankind. Why vote Socialist? For the redemption of political action from the depredation of old-party politics and its use as a means of our social salvation.

Why vote Socialist? For the sake of our immediate gains now in the midst of this crisis. Nothing will give us power at the City Hall, Albany or Washington, no matter whether Tweedledum or Tweedledee is elected so much as a tremendous Socialist vote. Nothing will so encourage the workers to build up the intelligent movement in which is our only hope." 2

Thomas covered thirty eight states during the campaign and made two hundred and fourteen speeches. He did most of his travelling in a second-hand automobile accompanied by his wife, Violet, who served as chauffeur, secretary, and maid-of-all-work. Thomas had already won a reputation as a good speaker and drew large crowds at almost every place in which he spoke. The Christian Science Monitor said in an editorial that "one cannot hear him deliver one of his campaign addresses without being stimulated to do some fresh and serious thinking."3

1 Speech over the National Broadcasting Company network, Madison, Wisconsin, November 7, 1932, Thomas Papers.

2 Speech at Madison Squarc Garden, New York Times, November 4, 1932, p. I6.

${ }^{3}$ Christian Science Monitor, November 2, 1932, p. I0. "Hc speaks at once with dignity and fire, with practical realism and sensitive imagination .... When he speaks it is the depth of conviction that counts primarily. But he is the fortunate owner of a rich, resonant voice, and has the gift of speaking at high speed yet with clarity and freedom from thetorical bombast." Devere Allen, Norman Thomas - Why Not?, in: Nation, CXXXIV (March 30, 1932), 365. Press accounts of the meetings addressed by Thomas referred to the unusually large crowds that turned out to hear him. In Philadelphia, according to the New York Times, the crowd that turned out for Thomas was the biggest at any Socialist gathering. Thomas spoke before one of the biggest political rallies ever held in the "ultraconservative" insurance city of Hartford. Thousands thronged to hear Thomas in Indiana- 
The most vocal support for Norman Thomas came from a segment of the American intelligentsia. These men and women were by no means believers in the Socialist ideology but they were repelled by the failure of the two major parties to propose adequate measures of reform. "I am no more a Marxist than I am a Mohammedan", said Elmer Davis, the noted journalist and publicist, while announcing his support of Thomas. "The Socialist program", explained Davis, "is the only one that seriously attempts to cure our disease; probably it will not win this fall, but if it commands strong support it may force the other parties to face a few facts and to consider national instead of local interests." "A great many of us are eager to vote for you", wrote historian Carl Wittke to Thomas, "because we want to pile up as large a Socialist protest vote as possible."

A large protest vote - that was the objective of many of the intellectuals who gave their support to the Socialist ticket in $1932 .^{\mathbf{3}}$ "Socialism in our time" was certainly not the slogan of most of them. On the other hand many of them were convinced that a good showing by the Socialist ticket in the national elections would pave the way for a new "liberal" third party that would quietly dispense with the Socialist label.4

To mobilize non-socialist support for the Socialist ticket, an organization known as the "Committee of One Thousand" was set up with Paul Douglas as chairman. The philosopher, John Dewey, was one of the vice-presidents of the organization and he wrote to several intellectuals soliciting political and financial support. Heartened by the initial response the organization changed its name to "Committee of One Hundred Thousand". That name was retained till the end of

polis whereas during the campaign of 1928 only two hundrcd had been present. (Edward Levinson to W. E. Woodward, September 12, 1932, Archives of the Socialist Party.) Large crowds turned out to hear Thomas in such places like Columbus, Ohio, and Madison, Wisconsin. In his own city of New York, Thomas addressed enthusiastic meetings including a huge rally in Madison Square Garden. For an account of the Madison Squarc Garden meeting, see New York Times, November 4, x932, p. I.

1 Davis, op. cit., 395 .

2 Wittke to Thomas, June 3, 1932, Archives of the Socialist Party.

${ }^{3}$ Some of them who belonged to the Lcague for Independent Political Action disclaimed the "socialist" label but expressed faith in the need for increased social control.

4 "The value of the vote for Thomas next fall", wrote Prof. Robert Morss Lovett, "will be in its protest against the present operations of political government. Only by the negative force of fear will it be able to effect any immediate change. A promise that a third party will be a serious contender in 1936 will be the most salutary result of the campaign of 1932, not only in consequence of the deterrent feat with which such a prophecy may strike the predatory forces now in control, but by virtue of the hope which it will give to the masses everywhere whose faith in the democratic process is almost gone." Robert Morss Lovett, Progressives at Cleveland, in: New Republic, LXXI (July 20, I932), 259 . 
the campaign, but the maximum membership attained by the Committee was only 9,393. $\mathrm{A}$ group of well known writers including Stuart Chase, Sephen Vincent Benet, Van Wyck Brooks, Upton Sinclair, Henry Hazlitt, George Kaufman, and Silas Bent sponsored a "Committee of Writers for Thomas and Maurer". In a statement the members of the Committee asserted that the need had become imperative "to organize intelligent Americans for economic planning radical enough to remove the cancer of our present day capitalistic anarchy." "We believe", they declared, "that in sincerity, courage and economic understanding he [Thomas] is personally superior to either Mr. Hoover or Mr. Roosevelt."2 Also active in supporting the Socialist ticket were American pacifists. In a poll of members of the largest organization of pacifists, the Fellowship of Reconciliation, Thomas held a commanding lead over the other candidates with a vote of 75. 1 per cent. ${ }^{3}$

Another interesting feature of the campaign was a remarkable political ferment among university students and the development of a significant volume of support for the Socialist ticket among them. The youthful "revolutionaries" of New York's Columbia University were agog with excitement when a poll of Columbia students showed Thomas with a clear lead over Hoover and Roosevelt." In a nationwide campus "straw poll", Hoover led comfortably, but the Thomas vote was impressive. "The most striking feature of the poll", according to a scribe in the student newspaper of Princeton University, "was the surprising showing of Thomas, the Socialist candidate, who led the voting in five colleges, carried Colorado and Missouri, and almost equalled Roosevelt's total in the East and the Middle West." 5 Under the active sponsorship of the national headquarters of the

1 Memorandum from the National Secretary to the National Executive Committee of the Socialist party of America, December 9, 1932, Archives of the Socialist Party. The office-bearers of the Committee were: Paul Douglas, chairman; Morris R. Cohen, John Dewey, Bishop Francis J. McConnell and Oswald Garrison Villard, vice-presidents; Reinhold Niebuhr, treasurer; Mary Fox, secretary.

2 New York Times, October 7, 1932, p. 13.

3 J. B. Matthews, Pacifists Prefer Thomas, in: World Tomorrow, XV (October 26, 1932), p. 402. Hoover, Roosevelt, and Foster obtained 20.4, 2.9, and 1.6 per cent of the votes respectively.

4 The results were as follows: Thomas 1,033; Hoover 833; Roosevelt 547; and Foster 21. James A. Wechsler, The Age of Suspicion (New York, I953), 40. To hundreds of young men, wrote Wechsler "the central figure in the campaign was tall, tircless Norman Thomas." Wechsler was seventeen years of age in 1932 and was an ardent Socialist. Later he migrated to the Communist camp, but split with the party after some years. He is now editor of the New York Post and is regarded as a liberal and an "anti-Communist". 5 Daily Princetonian, October 28, I932, p. I. Of 58,686 votes cast, Hoover received 29,289; Roosevelt 18,212; Thomas 10,470; Foster 715; and William Upshaw (Prohibition party) 103. None of the candidates carried his own alma mater! 
Socialist party, 274 Thomas-for-President Clubs were organized in colleges all over the country. ${ }^{1}$ Some of them were small and held only a few meetings. But in many of the clubs, according to the national secretary of the party, "the program outlined was followed carefully and considerable enthusiasm was aroused."2

The pitiful inadequacy of support from organized labor was the Achilles-heel of the Socialist party of America. The leaders of the American Federation of Labor were unwilling to give any recognition to the Socialist party. Only the Vermont State Federation of Labor chose to endorse the Socialist ticket. Emil Rieve, president of the American Federation of Full Fashioned Hosiery Workers was one of the few labor leaders who openly supported the Socialist nominees. He headed a Labor Committee for Thomas and Maurer and was able to secure endorsements from 139 persons in 26 unions. ${ }^{3}$ It was indeed a meager quantum of support for a party that had avowedly dedicated itself to the cause of labor.

The Socialist party failed miserably to win electoral support from farmers who were badly hurt by the depression. It lacked the organization, finances, and field workers to implement an effective campaign. The party was able to distribute some literature in seventeen states through 122 volunteers. "The response to these efforts was not as large as we had hoped.... The work of interesting farmers was dropped early in order to cut down the size of the deficit", recorded the National Secretary of the party. 4

No concerted attempt was made by the party to build up a strong base of support among the Negroes, who, according to Walter White of the National Association for the Advancement of Colored People, were ready for "the greatest political revolt... that has ever been

1 "Leaders of tomorrow, join our fighting band that all workers may soon be free. It is up to us, the students, to educate, organize, and make assured the classless society through the coming of socialism in our time", declared Paul Ritterskamp, chairman of the National Students' Committee in letters to prospective supporters in various colleges and universities. Ritterskamp to George R. Robinson, Lincoln College, Jefferson City, Missouri, October 7, 1932, Archives of the Socialist Party.

2 Memorandum from the National Sccretary to the National Executive Committee, December 9, 1932, ibid.

3 The following unions cndorsed the Socialist ticket: Federated Trades Council, Milwaukee, Wisconsin; International Association of Machinists, Local IOS 2, Milwaukee; Amcrican Federation of Full Fashioned Hosiery Workers, Local i I, Newark, New Jersey; Local 39, Philadelphia, Pennsylvania; and locals from Washington, New Jersey, and Milwaukec, Wisconsin; Cigar Makers International, Local 87, Brooklyn, New York; Amalgamated Clothing Workers, Chicago Joint Board; and labor unions in La Grande, Oregon and Huntington, West Virginia. Ibid.

4 Ibid. 
known in a national election". ${ }^{1}$ Norman Thomas followed the traditional Socialist approach of viewing the problem mainly as an economic one. "The establishment of economic justice and the end of a class division of society will rapidly help us recover our sanity concerning race relations", Thomas declared. Thomas disdained any appeal for support on racial grounds and scrupulously refrained from offering panaceas for eliminating the social disabilities of the Negroes. To what extent such a stand cost him the support of the Negroes, it is not easy to determine.

The Socialist party was grievously afflicted by lack of funds for an effective campaign. While the Democratic and Republican parties counted their campaign expenditure in millions of dollars, the Socialist party had a grand war chest of $\$ 25,663.36$ only. ${ }^{2}$ The Committee for Thomas and Maurer was able to collect only $\$ 17,302.3 \mathrm{I}^{3}$ The Socialist presidential nominee kept his personal expenditure to the minimum. A nineteen-day campaign swing cost only $\$ 229.41$. A tenday jaunt through New England was completed at a cost of $\$ 55.45 .^{4}$

With heavy demands on its slender resources, the national headquarters was barely able to keep its head above water. On election day, stretching his limbs after an arduous campaign, the national secretary lifted the telephone in his office to call a friend. It was dead - the company had disconnected it because of non-payment of charges. ${ }^{5}$ The "earnest young men" whom Thomas had placed in the national headquarters, led by the 28 -year old national secretary, Clarence Senior,

1 Quoted in World Tomorrow, XV (November 2, 1932), 425. White stated that Negroes were disappointed with the performance of Hoover, but had little hope in the Democratic party. "In retrospect", wrote 'Thomas to the writer, "I think that we socialists made a mistake not to particularize more on the race issue in behalf of Negrocs but I do not think it would have made much difference in the vote." Thomas to the writer, January 17, 1959. The Communist party, with a radically different approach specifically designed to appeal to the racially-minded Negro, had no better luck than the Socialist party. Perhaps, as Wilson Record says, Negroes "were too preoccupicd with staying alive and praising God (in that order) to give time to the building of the society." Record adds that Negroes were reluctant "to invite the stigma of radicalism when the stigma of race was already overwhelming." The Negro and the Communist Party (Chapel Hill, I95 I), II.

2 Memorandum from the National Secretary to the National Executive Committee, December 9, 1932, Archives of the Socialist Party. Of the amount cited, locals, branches, and state organizations owed $\$ 9,883.76$ to the party's national office.

3 Ibid.

4 Christian Science Monitor, October 28, 1932, p. 4. Here arc details of Thomas's expenses on his New England trip: meals $\$ \times 6.20$; gas and oil $\$ 22.65$; repairs and grease $\$ 4.85$; ferry charges and tolls $\$ 6.25$; public stenographer $\$ 4$; and incidentals $\$ 1$.50.

5 Clarence Senior to H. N. Sturgeon, Sioux City, Iowa, November 7, 1932, Archives of the Socialist Party. 
drove themselves unmercifully in the service of the party. ${ }^{1}$ The national headquarters mailed out over eight million pieces of campaign literature - a fourfold increase over the 1928 figures. A brightly edited campaign journal, America for All, carried articles from many writers and public figures who had endorsed the Socialist ticket. ${ }^{2}$

Many election prophets claimed that the Socialist party might poll the largest vote in its history. "The coming election will undoubtedly show a large increase in the Socialist vote", declared the St. Louis Star-Times. ${ }^{3}$ The Christian Science Monitor carried a report from its Washington bureau to the effect that the Socialist vote may tip the scale in some states. ${ }^{4}$ The New York Times paid a tribute to the quality of some of the Socialist candidates:

"... it is impossible to deny that the high character and special ability of some Socialist nominees make a strong appeal to nonSocialist voters who are in mental and spiritual revolt from the two leading political parties and who are thinking of voting the Socialist ticket on the principle that in this case it is men, not measures, that count. Such an inclination is almost certain to swell the vote of Mr. Norman Thomas far beyond the natural limits of his party." 5

Many Socialists and their allies were enthused by such rosy reports in the "capitalist" press and they were overjoyed when the Literary Digest predicted, on the basis of its national poll, that Thomas would receive two million votes. ${ }^{6}$ But as the campaign drew to a close, Thomas sensed the mounting public sentiment in favor of Roosevelt. "There's a strong Roosevelt sentiment throughout the country but it's based less on affection for or confidence in him than hatred of his opponent", said Thomas a few days before the election. "All this protest vote will go to Roosevelt and not to me." ?

1 "They worked for almost nothing and without them we would have got practically nowhere", Thomas wrote to the writer, January $17,1955$.

2 The journal reached a circulation of 120,000 in the last week of October, 1932, and was reported to be paying its way. After the election, however, the publication was discontinued owing to lack of funds.

3 Quoted in Literary Digest, CXIV (October I5, I932), ir.

4 Christian Science Monitor, October 24, I932, p. 3. The Monitor's coverage of the Socialist campaign, however, was very inadequate.

5 New York Times, November 4, 1932, p. I8. The newspaper predicted an unusually large "protest vote" in an editorial on November 3, 1932, p. 20.

- Literary Digest, CXIV (November 5, I 932), 44.

7 Time(Chicago, Illinois), XX (November 7, I932), I s. Thomas made a general prediction about the outcome of the election as early as February, 1932. He told a reporter for the Poughkeepsie Eagle-News that the Democratic party could beat Hoover with almost any candidate and that Governor Roosevelt would win, if he was nominated by his party. Quoted in the New York Times, February 27, 1932, p. 8. 
The American people went to the polls on November 8, 1932. The Socialist presidential candidate, after one of the most strenuous campaigns in his party's history conducted in the midst of the worst depression in the annals of America, polled 903,286 votes. Roosevelt received 22,815,539 votes while Hoover obtained 15,759,930. ${ }^{1}$ The American people had made their decisions on the weighty problems that confronted them. The New York Times proclaimed their verdict in banner headlines: ROOSEVELT WINNER IN LANDSLIDE! DEMOCRATS CONTROL WET CONGRESS...

"We are not discouraged by the results. Election day does not mark the end of the campaign for us. Rather it is the signal for the launching of a more far-reaching campaign of organization", wrote Thomas to one of his supporters soon after the elections. ${ }^{3}$ Thomas attributed the failure of the party to poll a larger vote to "the stampede of the herd which voted its hates without taking a chance on its hopes", and to the organizational weakness of the party itself. ${ }^{4}$ Many newspapers, in commenting on the elections, expressed a dim view of the future of the Socialist party. The Washington Post interpreted the result as proof that "in spite of hard times and discontent with existing conditions, the American people have no faith in Socialism."5 Describing Thomas as "by far the ablest candidate Socialism ever had in this country", the St. Louis Post-Dispatch argued that his vote demonstrated that "the Socialist cause, as a separate movement, has little to hope for." 6 Pessimism about the party's future was by no means confined to the editorial columns of newspapers. Its paralyzing tentacles reached into the ranks of the party itself.

While the Socialist vote was smaller than what had been expected, it still represented a fourfold increase over the 1928 figures. Indeed the Socialist party of America was one of the few labor and Socialist 1 New Leader (New York, N.Y.), XV (January 14, I 933), 8; Peel and Donnelly, op. cit., 230-3r. The Socialist party's presidential vote in 1932 was the second highest in its history. In 1920 Eugene Debs polled 919, 799 votes.

${ }^{2}$ New York Times, November 9, 1932, p. I.

3 Thomas to Horace S. Sourry, November 9, 1932, Archives of the Socialist Party.

4 Thomas to conference on organization, Socialist party headquarters, Chicago, November 9, 1932, Thomas Papers. Thomas told the writer that there were few Socialist watchers at polling booths and that a number of cascs were reported of failure of election officials to comply with regulations. It also happened, said Thomas, that the officials became tired after counting Republican and Democratic votes and were not too particular about counting the Socialist votes. Thomas told a story about a visit he once made to a polling booth in New York City. An official recognized him and greeted him warmly. "We are treating you right, Mr. Thomas. We arc giving you 26 votes", said the official. "Have you counted them all?" Thomas asked him. "Hell, no!" was the answer. Interview with Thomas, August, 1954.

5 Quoted in "The Socialist Avalanche that Failed", in: Literary Digest, CXIV (December 3, 1932), 10. 'T Ibid. 
parties in the world that registered political gains in the depression year of 1932.1 "Socialism recently... has met with serious setbacks", bemoaned Emile Vandervelde, eminent Belgian radical and head of the Labor and Socialist International, in a message to his American comrades. "There is not one of the great powers that has not at its head a conservative or fascist government." 2 In the light of such circumstances American Socialists need not have allowed themselves to be discouraged by the size of their vote. "Indeed my principal fear of the numerical results of the election" wrote Thomas to a conference on party organization, "is not its minor blow to our pride or its greater blow to our prestige and usefulness in public affairs but the possible adverse effect it may have on our growing organization."3 His fears proved to be only too true. But if the election results stunned many Socialists, they had an even greater impact on many of the "independents" and "progressives" who had endorsed the Socialist ticket. Thomas's post-election appeal to members of the Thomas and Maurer Committee to join the Socialist party brought forth little response. Several of them quietly put an end to their flirtation with the Socialist party and resumed their "independence". Before long many of them - as indeed millions of other Americans - began to respond to the vigorous leadership that Franklin D. Roosevelt provided. The dynamic leadership of Roosevelt and the tremendous popular enthusiasm that he was able to generate soon after his installation in the White House were hardly anticipated by the Socialist leaders. "Democratic failure which is inevitable will be found to play into our hands. We must be ready" 4, said Thomas two days after the national election. "Disillusionment in the Roosevelt regime will probably set in at an early stage of his administration", prognosticated another Socialist leader, Louis Waldman of New York. ${ }^{5}$ Such hopes were speedily nullified. Many who had harbored misgivings about the two major political

1 In 1928 the party polled 262,805 votes.

2 March of Socialism, op. cit., I6. Only a few months earlier British Socialism had suffered a crushing defeat, its Parliamentary representation being out from 288 to a mere 52 seats. The German Social Democratic party, the strongest unit in the Labor and Socialist International, was fighting with its back to the wall against the growing might of Hitler's Nazis. In fact, the Socialist movement found itself in a stalemate everywhere except in the Scandinavian countries and Spain.

3 Thomas to conference on organization, November 9, 1932, Thomas Papers.

4 Ibid.

5 Waldman to National Executive Committee, December 6, 1932, Archives of the Socialist Party. "I predict", wrote Daniel Hoan, Socialist Mayor of the city of Milwaukee, "that as Roosevelt fails, as he surely will, as his party will not let him promote real remedies, therc will be a swing towards the Socialist Party." Hoan to Frank G. Crane, Kalamazoo, Michigan, November, I932, Daniel W. Hoan Papers, Milwaukee County Historical Society, Milwaukee, Wisconsin, 
parties as instruments for social reform, began to rally around Roosevelt's Democratic party.

$$
* *
$$

The coming of the Great Depression did not significantly counteract the effect of any of the factors that operated against the development of a powerful Socialist movement in the United States. Despite widespread distress the overwhelming majority of the American people clung to the belief that their ailing economic system would right itself and continue to ensure for them a standard of living higher than that of any other nation. The deep-rooted faith of the American people in the traditional "system" of the two major parties remained, by and large, unshaken. The reaction of millions of Americans to the sufferings caused by the depression followed a traditional pattern. They decided to "turn the rascals out" and elected a Democratic President and Congress.

Leaders of organized labor did not relax their suspicion of "radical" political parties even during the period of mass unemployment and distress. Workers who were fortunate enough to retain their jobs did not want to run the risk of association with "radicals". The unemployed were, on the whole, unwilling to engage in any program of "direct action". It was only a relatively small group of Americans - the socially-conscious segment of the intelligentsia - that was galvanized into militant opposition to the two major parties. They were dissatisfied by the electoral campaign of the nominees of the two major parties on the ground that it showed an inadequate appreciation of the gravity of the distress caused by the depression.

The Socialist party of America possessed neither the organization nor the financial resources needed to create a great mass movement in the United States in 1932. Despite various handicaps, Norman Thomas waged a vigorous campaign and polled the second highest Socialist vote for the presidency. But many Socialists had optimistically expected a far greater response from the public. The resulting frustration intensified factional squabbles and greatly weakened the party. The outstanding qualities of leadership displayed by Roosevelt and the popularity of the legislative measures that he sponsored - neither of which had been anticipated by Socialists - served further to make the party a factor of minor importance on the American political scene. The party continues to exist today and the valiant Thomas is still active as the doyen of American Socialism. But its membership and influence are only a fraction of what they were during the exciting campaign of 1932 . 